ARCHIWA - KanCELARIE - ZBIORY

NR 1 (3)/2010

WANDA K. ROMAN

\title{
Archiwum Kazimierza Sabbata
}

(O) d kilku lat toczy się dyskusja na temat dokumentacji wytworzonej i zgromadzonej przez polską emigrację na świecie, przede wszystkim na temat miejsca jej przechowywania. Wśród tych materiałów znaczną część, a biorąc pod uwagę zawartość, nie mniej ważną niż dokumentacja instytucji związanych z polskimi władzami na uchodźstwie, stanowią spuścizny archiwalne. Poruszane są zagadnienia właściwego zabezpieczenia całości archiwaliów polskich znajdujących się poza granicami kraju, ich opracowania oraz udostępniania do różnych celów, głównie naukowych ${ }^{1}$. Zgodnie z poglądem

Wanda K. Roman - Instytut Historii i Archiwistyki Uniwersytetu Mikołaja Kopernikaw Toruniu, e-mail: wandakr@umk.pl. Zainteresowania badawcze: naukowa informacja archiwalna, archiwoznawstwo ze szczególnym uwzględnieniem archiwów i archiwaliów wojskowych, prywatnych oraz emigracyjnych, źródłoznawstwo, warsztat badawczy historyka i archiwisty, historia, historiografia i biografistyka (w tym wojskowa) XX w.

1 Por. D. Wodecka, Strażnicy świętej emigracji [on-line]. [Dostęp 1 września 2008 r.]. Dostępny w World Wide Web: http://wyborcza.pl/1,76498,5642092,Straznicy_swietej_ emigracji.html. Por. również: W. K. Roman, Spuścizny archiwalne polskiej emigracji oraz ich zabezpieczanie, opracowanie i udostepnianie na przyktadzie Archiwum Kazimierza Sabbata, [w:] Paryż - Londyn - Monachium - Nowy Jork. Powrześniowa Emigracja Niepodlegtościowa na mapie kultury nie tylko polskiej, red. V. Wejs-Milewska, E. Rogalewska, Białystok 2009, s. 579-595; Sprawa archiwów polskich w Orchard Lake [on-line]. [Dostęp 12 marca 2010 r.]. Dostępny w World Wide Web: http://mira888.salon24.pl/104491,listotwarty-do-arcybiskupa-detroit-w-spawie-orchard-lake; J. Hofman-Wiśniewska, Wę- 
funkcjonującym zwłaszcza w środowiskach polskich za granicą, zadanie gromadzenia zbiorów emigracyjnych oraz ich zabezpieczenia należy do instytucji emigracyjnych, które są utrzymywane przez akcję publiczną, ponieważ nie straciły one swych funkcji wobec społeczeństwa, na rzecz którego działały i działają. Przeciwne stanowisko, które jednak z czasem zyskuje coraz mniej zwolenników, mówi o tym, że tylko w Polsce, w państwowych archiwach i bibliotekach, można zapewnić emigracyjnym zbiorom archiwalnym właściwą ochronę.

Przed kilku laty w polskich środowiskach emigracyjnych oraz w Polsce toczyła się szeroka dyskusja na temat miejsca przechowywania dorobku kulturalnego polskiej emigracji - zarówno archiwalnego, jak i księgozbiorów oraz muzealiów. Dla przykładu, dwa stanowiska - emigracyjne i krajowe. Eugenia Maresch, działaczka społeczna zamieszkała w Anglii od ponad sześćdziesięciu lat, m.in. członek Rady Polskiego Ośrodka Społeczno-Kulturalnego w Londynie i krajowej Rady Dziedzictwa Archiwalnego, podczas II Zjazdu Polonii i Polaków z Zagranicy w 2001 roku mówiła:

Sprawa gromadzenia zbiorów emigracyjnych oraz ich zabezpieczenia głównie spada na instytucje, które zostały do tego celu powołane, a utrzymywane przez akcję publiczną. Śmiem twierdzić, że przynajmniej na Zachodzie nie brak pieniędzy, z których instytucje kulturalne mogłyby czerpać [...] instytucje emigracyjne nie straciły swych funkcji ani zadań wobec społeczeństwa, w którym przyszło nam żyć i przyjdzie umierać oraz dla Kraju, który je chce poznać. Coraz częściej się zdarza, że dokumenty i dzieła sztuki do niedawna w prywatnych rękach są przekazywane do Polski. Decyzja prywatnego dobroczyńcy jest sprawą indywidualną, choć przyjmowaną przez opinię naszą bez oporu, z czasem staje się zawodem dla samego darczyńcy. Inaczej przedstawia się rzecz ze zbiorami należącymi do ogółu społeczeństwa, które nazwę dziedzictwem narodowym, wprawdzie wytworzonym przez Emigrację, ale świadomą swojej narodowej roli. Jest to misja twórcza, która po półwiecznej izolacji potrzebuje ożywionych wszechstronnych kontaktów².

drówki zapisanych myśli [on-line]. [Dostęp 6 maja 2007 r.]. Dostępny w World Wide Web: http://www.sprawynauki.waw.pl/?section=article\&art_id=1392; E. Maresch, Zachowanie kultury narodowej $i$ wspieranie instytucji polskich w świecie [on-line]. [Dostęp 6 maja 2007 r.]. Dostępny w World Wide Web: http://www.wspolnota-polska.org.pl/index.php?id=marpz2; Rozmowa $z$ Ludomirem Garczyńskim-Gąssowskim [on-line]. [Dostęp 6 sierpnia 2008 r.]. Dostępny w World Wide Web: http://www.poloniainfo.se/artykul. php?id=456; Wystapienia podczas konferencji „Polska kultura emigracyjna i dziedzictwo narodowe za granica" 25 maja 1999 roku [on-line]. [Dostęp 6 sierpnia 2008 r.]. Dostępny w World Wide Web: http://www.senat.gov.pl/k4/kom/ksep/8.htm.

${ }^{2}$ E. Maresch, dz. cyt. 
Z kolei w 2004 roku Hanna Łaskarzewska, przedstawicielka Ministerstwa Kultury i Dziedzictwa Narodowego, mówiła:

Na pewno nie wszystkie [archiwalia - przyp. W. K. R.] powinny się znaleźć w kraju, bo tam, gdzie jest żywa Polonia, gdzie są fachowe instytucje, które zajmują się gromadzeniem, przechowywaniem i opracowywaniem tych zbiorów, powinny to robić nadal, ale... Niepokoi, co się stanie z tymi zbiorami, gdy zaczną odchodzić ludzie się nimi zajmujący. Musieliby „przejąć sztafetę” młodzi. A oni się do tego nie palą. Trzeba by im godziwie zapłacić - na to brakuje funduszy. Kto ma łożyć na utrzymanie tych instytucji? Państwo, w którym one się znajdują? Czy Polska? I wreszcie: zbiory muszą być modernizowane, tzn. sposób ich utrzymania, katalogowania, udostępniania, trzeba by je skomputeryzować, aby każdy mógł szybko i łatwo zorientować się, co w nich jest. Środowiska polonijne nie mają na to pieniędzy. Nasze Ministerstwo Kultury wyasygnowało spore pieniądze na pomoc dla bibliotek poza granicami kraju ${ }^{3}$.

Trzeba dodać, że pomoc ta objęła również inne polskie placówki, które gromadzą archiwalia, muzealia i książki, często jednocześnie. Wsparcie to jednak w sposób zauważalny widać dopiero w ostatnich kilku latach ${ }^{4}$. Instytucje polonijne na świecie ${ }^{5}$ oraz archiwa zagraniczne ${ }^{6}$ przechowują setki spuścizn prywatnych wytworzonych przez przedstawicieli polskich środowisk emigracyjnych. Spuścizny archiwalne, które znalazły się w placówkach pub-

3 Cyt. za: J. Hofman-Wiśniewska, dz. cyt.

${ }^{4}$ Od ponad 10 lat Naczelna Dyrekcja Archiwów Państwowych współpracuje z polskimi środowiskami za granicą, udzielając fachowej pomocy w porządkowaniu i ewidencjonowaniu zbiorów, dzięki wsparciu finansowemu z Ministerstwa Kultury i Dziedzictwa Narodowego. W 2007 r. pomoc ta objęła 8 instytucji poza krajem, w 2008 r. - 15 placówek polskich w Europie i obu Amerykach. Obecnie Naczelna Dyrekcja Archiwów Państwowych współpracuje z 19 instytucjami polskimi poza krajem, por. Pomoc instytucjom polonijnym [on-line]. [Dostęp 11 marca 2010 r.]. Dostępny w World Wide Web: http://www.archiwa.gov.pl/lang-pl/wspolpraca-i-projekty/instytucje-polonijne/1050-pomoc-instytucjom-polonijnym.html. Staraniem NDAP opublikowano również Poradnik dla archiwisty instytucji polskiej na obczyźnie, red. J. Krochmal, Warszawa 2006.

5 W tym największe: Instytut Polski i Muzeum im. gen. W. Sikorskiego w Londynie, Instytuty Józefa Piłsudskiego w Londynie i Nowym Jorku, Biblioteka Polska Polskiego Ośrodka Społeczno-Kulturalnego w Londynie, Archiwa, Biblioteki i Muzea Polonii w Orchard Lake w USA.

${ }^{6}$ Najwięcej archiwaliów polskiej proweniencji, w tym prywatnych, przechowuje Instytut Hoovera, por. W. Stępniak, Archiwalia polskie w zbiorach Instytutu Hoovera Uniwersytetu Stanforda, Warszawa 1997. 
licznych, otrzymały więc szansę na zabezpieczenie i fachową opiekę merytoryczną.

Jednak należy pamiętać, że spuścizna archiwalna stanowi własność prywatną, a więc tylko właściciele decydują o tym, gdzie ich zbiory znajdą swoje miejsce. Przekazanie ich (lub nieprzekazanie) do określonej, wybranej placówki jest zawsze indywidualną decyzją właściciela lub dysponenta. Z jednej strony obserwujemy tendencję do sprowadzania spuścizn prywatnych do kra$\mathrm{ju}^{7}, \mathrm{z}$ drugiej zaś w środowiskach emigracyjnych jest zauważalny nacisk na to, aby pozostawały one w miejscach, z którymi był związany ich twórca. Słuszne wydaje się to drugie podejście, albowiem można je przyrównać do archiwalnej zasady pertynencji terytorialnej. W zupełnie innym kontekście, szerzej, obiektywniej można spojrzeć na spuściznę archiwalną w warunkach, w których tworzył i działał jej twórca. Często osobę twórcy i jego dorobek lepiej rozumie się w integracji np. z innymi, podobnymi archiwaliami lub - jeśli znajduje się w rękach prywatnych - w otoczeniu mu najbliższym.

Wiele materiałów archiwalnych wytworzonych przez wybitnych emigracyjnych polityków, twórców, działaczy politycznych i społecznych pozostaje w rękach prywatnych. O tym, że istnieją, wiadomo najczęściej z publikacji naukowych, których autorzy korzystali z ich zawartości. Stan tych zbiorów, jeśli chodzi o sposób przechowywania, opracowanie i udostępnianie, jest bardzo zróżnicowany. Wydaje się bezsprzeczne, że obecni właściciele tych - często cennych materiałów - potrzebują fachowej, rzetelnej pomocy, jeśli chcemy, aby służyły one ogólnonarodowemu dobru.

W misję utworzonej w 1998 roku Rady Dziedzictwa Archiwalnego, skupiającej przedstawicieli Polaków z kraju i zagranicy, wpisano, że

Należy zrobić wszystko, by zachować pamięć i by nie zmarnować dorobku ludzi i pokoleń walczących o Polskę niepodległą i o polskość, by zachować zbiory prywatne, zwłaszcza działaczy, osób zasłużonych dla środowisk polskich, naukowców, inżynierów i ludzi pióra, ale także tych wszystkich, którzy zgromadzili archiwa domowe dokumentujące losy uchodźców politycznych, emigrantów i tych, którzy czuli się związani z polskością. Szczególnie narażone są na zniszczenie archiwa osobiste i rodzinne, dla których nieraz brak zainteresowania u spadkobierców lub u osób przejmujących spuściznę

7 W Polsce istnieje kilkadziesiąt miejsc (biblioteki, archiwa, muzea), w których znalazły się prywatne archiwalia wytworzone przez polskich emigrantów, które różnymi drogami trafity do kraju. Szerzej patrz W. K. Roman, dz. cyt., s. 582-583.

${ }^{8}$ Rada Dziedzictwa Archiwalnego [on-line]. [Dostęp 12 maja 2007 r.]. Dostępny w World Wide Web: http://www.archiwa.gov.pl/lang-pl/ciala-kolegialne/65-rada-dziedzictwa-archiwalnego.html. 
Główne zasady, którymi miała się kierować Rada, to: po pierwsze - zabezpieczenie zbioru przed zniszczeniem lub zaginięciem ważniejsze jest od pozyskania zbioru dla jednego z wielkich zbiorów publicznych; po drugie - pomoc będzie adresowana do wszystkich, bez względu na ich związki organizacyjne czy też powiązania personalne z Radą lub innymi instytucjami; po trzecie - poszanowanie autonomii i praw każdej instytucji oraz osoby prywatnej, która zwróci się do Rady z chęcią współpracy lub z prośbą o pomoc, a także poszanowanie suwerenności decyzji tych instytucji i osób.

Archiwum Kazimierza Sabbata, przedostatniego prezydenta Rzeczypospolitej Polskiej na uchodźstwie, wcześniej wieloletniego premiera i ministra spraw zagranicznych rządu emigracyjnego, aktywnego działacza politycznego i społecznego Polonii w Wielkiej Brytanii, zawierające materiały archiwalne zgromadzone przez kilkadziesiąt lat jego życia, jest własnością prywatną. Należy do rzadkich przypadków troski rodziny nie tylko o zabezpieczenie całości materiałów, ale również o zapewnienie możliwości ich udostępniania, a w przyszłości przekazania do archiwum w postaci uporządkowanej. Opracowanie tej spuścizny jest wynikiem prywatnych kontaktów autorki niniejszego artykułu i rodziny prezydenta Kazimierza Sabbata - a więc - jak często w sprawach zbiorów prywatnych - zadecydował przypadek.

Kazimierz Aleksander Sabbat urodził się w 1913 roku w Bielinach Kapitulnych w Kieleckiem, w rodzinie wiejskiego organisty ${ }^{9}$. Lata dziecięce spędził w Trzciance, niewielkiej wsi w powiecie staszowskim. Po ukończeniu szkoły powszechnej w Tursku Wielkim, w 1926 roku wstąpił do Państwowego Gimnazjum w Mielcu. Tam zainteresował się ruchem skautowym i harcerskim i został członkiem Związku Harcerstwa Polskiego. Po zdaniu egzaminu maturalnego, w roku 1932 został powołany do odbycia zasadniczej służby wojskowej w Szkole Podchorążych Rezerwy 4. Pułku Piechoty Legionów w Kielcach. Jesienią 1933 roku wstąpił na Wydział Prawa Uniwersytetu J. Piłsudskiego w Warszawie, ale z powodów finansowych studia podjął dopiero dwa lata później. W tym okresie zafascynowała go polityka, więc równolegle ze studiami prawniczymi podjął naukę w Szkole Nauk Politycznych w Warszawie. Prawo skończył przed wybuchem wojny, ale na Wydziale Politycznym zaliczył tylko dwa semestry, chociaż tej pasji pozostał wierny do końca życia. Sabbat kontynuował również zainteresowania ruchem har-

9 Szerzej: J. K. Danel, Kazimierz Sabbat. Rys biograficzny, Mielec 2000; tenże, Kazimierz Sabbat (1913-1989) polityk i mąż stanu, Niepodległość, t. 39, 2000-2001, s. 7-28; tenże, Kazimierz Sabbat polityk i mąż stanu 1913-1989. Biografia polityczna, Poznań 2005 [mps pracy doktorskiej]; W. K. Roman, Wstęp, [w:] K. Sabbat, Polska na drodze do wolności i niepodlegtości. Pisma polityczne, wyb. i oprac. W. K. Roman, Toruń 2009, s. 17. 
cerskim. Został aktywnym członkiem Kręgu Starszoharcerskiego studentów uniwersytetu oraz inicjatorem założenia Zrzeszenia Akademickich Kręgów Starszoharcerskich „Kuźnica”, które podczas wojny w dużej mierze stało się bazą do zorganizowania Głównej Kwatery Szarych Szeregów.

Po wybuchu wojny we wrześniu 1939 roku Sabbat otrzymał przydział mobilizacyjny i został skierowany do Ośrodka Zapasowego 25. Dywizji Piechoty w Czortkowie. Tu zastał go atak Armii Czerwonej na ziemie wschodnie Drugiej Rzeczypospolitej. W zamieszaniu i panice, wobec braku jakichkolwiek informacji i dowództwa, grupa żołnierzy, którym przewodził Sabbat, przedarła się przez tereny zajęte przez Rosjan, prawie osiągając granicę polsko-węgierską. W Tyśmienicy kompania jednak rozpadła się i Sabbat, wraz z jednym tylko żołnierzem, przeszedł na Węgry. Po złożeniu broni 21 września stał się jednym z tysięcy internowanych polskich żołnierzy. Dzięki dawnemu znajomemu, niegdyś węgierskiemu skautowi, ministrowi spraw wewnętrznych Istvanowi Gaborowi otrzymał zadanie zorganizowania obozu harcerskiego dla polskiej młodzieży, którego został komendantem. Ułatwiło mu to wydostanie się z obozu dla internowanych i ucieczkę. W styczniu 1940 roku, przez Jugosławię i Włochy, przedostał się do Francji. W Armii Polskiej otrzymał przydział do Marynarki Wojennej. Po ewakuacji Wojska Polskiego na Wyspy Brytyjskie przydzielono go najpierw do 10. Brygady Kawalerii Pancernej gen. Stanisława Maczka w Szkocji, a następnie w 1943 roku - już w stopniu podporucznika - do Sztabu Głównego Polskich Sił Zbrojnych, mieszczącego się w Londynie. Wyznaczono go na stanowisko referenta do spraw młodzieży. Wkrótce też Sabbat został wiceprzewodniczącym Komitetu Naczelnego ZHP na Czas Wojny, a faktycznie objął kierownictwo nad harcerstwem polskim za granicą.

Po zakończeniu wojny Kazimierz Sabbat zdecydował się pozostać na emigracji, gdzie, jak uważał, najlepiej może służyć ojczyźnie i działać na rzecz odzyskania niepodległości. W celu zdobycia podstaw finansowych, które umożliwiłyby mu zajęcie się działalnością publiczną, w 1947 roku założył przedsiębiorstwo produkcyjne „Limba”. Jednocześnie aktywnie uczestniczył w życiu społecznym i politycznym polskiego wychodźstwa w Wielkiej Brytanii. Był członkiem Naczelnictwa Związku Harcerstwa Polskiego. Pełnił funkcję komisarza zagranicznego oraz Kierownika Starszego Harcerstwa i był aktywnym działaczem na rzecz współdziałania polskiego harcerstwa z organizacjami skautowymi zrzeszonymi w Światowym Biurze Skautowym. Kazimierz Sabbat współorganizował koło Stowarzyszenia Polskich Komba- 
tantów $(\mathrm{SPK})^{10}$ nr 114, które na swojego prezesa wybrało gen. Nikodema Sulika, dowódcę 5. Kresowej Dywizji Piechoty.

Przez wiele lat był członkiem Prezydium Rady Głównej Stowarzyszenia Polskich Kombatantów. W roku 1960 został prezesem Niezależnej Grupy Społecznej (NGS) ${ }^{11}$. W roku 1954 wszedł do Egzekutywy Zjednoczenia Narodowego (EZN), powołanej w miejsce rządu prezydenckiego ${ }^{12}$. W EZN sprawował funkcję kierownika Działu Skarbowego i kierownika Działu Spraw Emigracji. Jako szef tego ostatniego w 1962 roku organizował Pierwszy Ogólny Zjazd Polaków w Wielkiej Brytanii, a w 1966 roku milenijny Światowy Zjazd Polski Walczącej. W latach 1967-1972 był przewodniczącym EZN. Od tego momentu stał się jedną z centralnych postaci polskiej emigracji niepodległościowej. W tym okresie zainicjował i współorganizował Kongres Nauki i Kultury Polskiej w Wolnym Świecie, który odbył się w 1970 roku w Londynie. W latach 1972-1976 aktywnie działał jako przewodniczący NGS i członek Rady Narodowej RP13. Był też członkiem i, w pewnym okresie, sekretarzem generalnym Polskiego Komitetu Ruchu Europejskiego ${ }^{14}$.

10 Stowarzyszenie Polskich Kombatantów powstało w 1946 r. w Londynie w miejsce Samopomocy Wojskowej. Skupiało lokalne organizacje kombatanckie (koła) działające w krajach osiedlenia się żołnierzy Polskich Sił Zbrojnych na Zachodzie.

11 Niezależną Grupę Społeczną zawiązało w czerwcu 1949 r. pięciu członków Rady Narodowej RP na uchodźstwie. Jej celem było wówczas doprowadzenie do udziału w pracach Rady jak największej liczby członków pochodzących z wyborów. Założenie NGS uważano za bunt działaczy społecznych przeciwko stronnictwom politycznym. NGS odegrała bardzo ważną rolę w dziejach emigracji.

12 Wówczas Rada Jedności Narodowej (por. przyp. 35) uchwaliła pozbawienie prezydenta Augusta Zaleskiego prawno-politycznych i moralnych podstaw do sprawowania urzędu i 8 sierpnia 1954 r. powołała tzw. Radę Trzech, która miała zastępować prezydenta w okresie kryzysu państwowego, oraz EZN zamiast rządu. Od tego momentu datuje się kilkunastoletnie rozbicie polityczne emigracji. W lipcu 1956 r. EZN otrzymała od Rady Trzech uprawnienia rządu. Rozwiązana w 1972 r., po objęciu urzędu prezydenta przez Stanisława Ostrowskiego i zjednoczeniu rozbitej emigracji.

13 Rada Narodowa RP została powołana przez prezydenta W. Raczkiewicza 9 grudnia 1939 r. we Francji jako organ doradczy i opiniodawczy rządu i prezydenta polskiego na emigracji, namiastka parlamentu. Rozwiązana po konferencji jałtańskiej w 1945 r. i reaktywowana w 1949 r. na podstawie dekretu prezydenta A. Zaleskiego jako przeciwwaga dla Rady Politycznej. Rozwiązała się w 1991 r. wobec zmian ustrojowych, które dokonały się w Polsce.

14 Polski Komitet Ruchu Europejskiego był elementem ogólnoeuropejskich dążeń do utworzenia zjednoczonej Europy. W czerwcu 1947 r. w Paryżu zorganizowano Komitet Koordynacyjny Ruchów Międzynarodowych na rzecz Jedności Europejskiej. Po 
Na początku lat siedemdziesiątych Sabbat był inicjatorem rozmów o połączeniu zwaśnionych od lat pięćdziesiątych ośrodków emigracyjnych stojących na stanowisku ciągłości prawnej państwa polskiego, które zakończyły się pojednaniem w 1972 roku po objęciu prezydentury przez prof. Stanisława Ostrowskiego ${ }^{15}$. W 1976 roku Sabbat został wyznaczony przez niego na stanowisko prezesa Rady Ministrów oraz jednocześnie mianowany ministrem spraw krajowych i ministrem sprawiedliwości rządu Rzeczypospolitej Polskiej na uchodźstwie. W latach, kiedy Sabbat był premierem, zaktywizowała się w Polsce opozycja demokratyczna i niepodległościowa. Był on zaangażowany prawie we wszystkie przedsięwzięcia na rzecz pomocy krajowi, a przez jego dom przewijali się liczni działacze opozycyjni z Polski. Organizował i wspomagał fundusze, rozbudował Skarb Narodowy ${ }^{16}$, współorganizował i aktywnie uczestniczył w II Światowym Zjeździe Jedności z Walczącym Krajem w 1979 roku. Zaprzysiężony w 1979 roku kolejny prezydent RP na uchodźstwie Edward Raczyński ponownie powierzył misję sformowania rządu Sabbatowi, którego następnie w lutym 1980 roku wyznaczył na swojego następcę na urzędzie prezydenta, co wywołało gwałtowne spory i protesty, szczególnie ze strony dawnych zwolenników Augusta Zaleskiego. Niemniej jednak pozycja Sabbata była silna, a on sam „wysuwał się na czoło jako człowiek rozumny, widzący lepiej od wielu innych postępujące zmiany, potrzebę szukania nowego języka w dialogu z ludźmi z Polski, akceptowania programu minimum dla kraju, a nie jedynie trwania w polityce deklaracji"17. Do najistotniejszych inicjatyw na forum międzynarodowym rządu emigracyjnego, którym kierował Sabbat, należało przygotowanie w lutym i listopadzie 1982 roku dwóch memoriałów na temat sytuacji w Polsce w pierwszym roku stanu wojennego. Zostały one dostarczone wszystkim uczestnikom pohelsińskiej konferencji zorganizowanej w Madrycie ${ }^{18}$. Dnia 8 kwietnia 1986 roku Sabbat został zaprzysiężony jako prezydent RP - piąty na uchodźstwie. Jako premier i prezydent wizytował ośrodki polonijne na świecie, utrzymywał kontakty

Kongresie Europejskim w Hadze, w 1949 r. utworzono Radę Europy, która zapoczątkowała serię konferencji Ruchu Europejskiego.

15 Por. przyp. 12.

16 Instytucję Skarbu Narodowego powołano dekretem prezydenta Rzeczypospolitej z dnia 14 października 1949 r. Siedzibą Głównej Komisji Skarbu Narodowego był Londyn. Funkcjonowały również terytorialne Komitety Skarbu Narodowego, które zajmowały się zbieraniem środków pieniężnych i materialnych dla zapewnienia funkcjonowania władz Rzeczypospolitej Polskiej na emigracji.

${ }^{17}$ A. Friszke, Życie polityczne emigracji, Warszawa 1999, s. 419.

18 Por. M. Szczurowski, Rząd Rzeczypospolitej Polskiej na Uchodźstwie i emigracja polska w Londynie wobec stanu wojennego, Dzieje Najnowsze, R. 37, 2005, nr 3, s. 119-128. 
z przedstawicielami podziemnej „Solidarności”. Przez wiele lat prowadził aktywną działalność publicystyczną, zajmując się ważnymi sprawami krajowymi i międzynarodowymi. Wiele jego tekstów, w tym oficjalne przemówienia, publikowały czołowe tytuły prasy emigracyjnej, głównie londyńskiej, jak „Dziennik Polski i Dziennik Żołnierza” i „Rzeczpospolita”.

W 1949 roku Sabbat ożenił się z Anną Sulik, córką generała Nikodema Sulika, która przez całe jego życie wspierała go we wszystkich przedsięwzięciach, nie tylko wychowując czworo dzieci i przejmując wiele obowiązków, ale również pracując społecznie.

Kazimierz Sabbat zmarł nagle 19 lipca 1989 roku, w przeddzień wydarzeń, na które czekał, w które wierzył i o które walczył - przemiany Polski w państwo demokratyczne i wolne.

Archiwum było gromadzone przez Sabbata od lat studenckich, przez lata wojny, emigracji, do chwili śmierci. Twórca pieczołowicie zbierał wszystkie, najdrobniejsze nawet materiały, nie tylko ważne dokumenty osobiste, świadectwa, mianowania na stanowiska, listy i własne rękopisy w różnych etapach powstawania, ale również - z punktu widzenia użyteczności naukowej niewiele warte - pokwitowania, niewykorzystane kupony ubraniowe czy notatki na kawiarnianych serwetkach. Natomiast z punktu widzenia archiwisty i badacza znakomicie odzwierciedlają one obecnie różne momenty i fragmenty życia twórcy, a także pewne cechy charakteru. Materiały przedwojenne przebyły wraz z Kazimierzem Sabbatem wędrówkę z Polski, przez Węgry i Francję, do Wielkiej Brytanii. Na każdym etapie powiększały się o kolejne, związane $\mathrm{z}$ aktualnym statusem i życiem twórcy.

Trudno jednak mówić o planowym i systematycznym tworzeniu archiwum przez Kazimierza Sabbata. To raczej niechęć do wyrzucania jakiegokolwiek papierka, który mógł się przydać w jego szerokiej i różnorodnej działalności. Można przypuszczać, że brak czasu nie pozwolił mu nigdy na zastanowienie się nad sensem gromadzenia wszystkiego, a na wszelki wypadek pozostawiał wszystko. Najczęściej było to odkładanie przeczytanych gazet, wykorzystanych lub nieaktualnych dokumentów czy kolejnego, otrzymanego listu (wraz z kopertą) do pudła, czasem wraz z kopią odpowiedzi. Świadczyła o tym zawartość niektórych pudeł i zachowana chronologia znajdujących się w nich materiałów. Sabbat miał zwyczaj robienia notatek w każdej chwili, podczas każdej rozmowy, dyskusji czy rozmyślań nad bieżącymi sprawami. Niestety, do chwili opracowania, wytworzone i zgromadzone materiały nie przetrwały w całości. Zniszczenie pewnej części archiwaliów (trudno dziś określić, jak dużej, ale sądząc po brakach np. w chronologii korespondencji, musiało to być kilka pudeł) było dziełem przypadku. Ze względu na dużą ilość „papierów” część z nich była przechowywana w domowej piwnicy, gdzie pod- 
czas awarii kanalizacji zostały zalane i niemożliwe było ich uratowanie. Mimo to zawartość zachowanej spuścizny stanowi odbicie wszystkich etapów życia prywatnego i działalności polityczno-społecznej Kazimierza Sabbata oraz życia polskiej emigracji w Wielkiej Brytanii po drugiej wojnie światowej.

Próbę uporządkowania materiałów Sabbata podjęto już w latach dziewięćdziesiątych. Objęto nim wówczas niewielki (ok. 1/2 m.b.) i dość przypadkowy fragment, nadając mu układ chronologiczny. $\mathrm{Z}$ uwagi na to, że nie miało to nic wspólnego z opracowaniem naukowym spuścizny, układ ten nie został zachowany podczas kolejnych, właściwych prac archiwalnych, trwających w latach 2001-2008. Opracowanie zakończono sporządzeniem inwentarza książkowego. Prace wykonywała autorka niniejszego artykułu, a długość ich trwania wynikała z ich cykliczności (raz w roku przez 2-3 tygodnie). Rzeczywisty czas opracowania to około sześciu miesięcy, z których ponad dwa miesiące poświęcono wyłącznie na prace fizyczne oraz rozpoznanie materiałów i na prace końcowe - opis (oklejenie) teczek i opracowanie wstępu do inwentarza. Opracowanie spuścizny Kazimierza Sabbata zostało podzielone na etapy. Pierwszy etap stanowiło zapoznanie się z całością materiałów i wstępna segregacja. Jak większość spuścizn, ta również obejmowała przede wszystkim materiały luźne, niezaopatrzone w żaden spis, umieszczone dość przypadkowo w pudłach kartonowych różnej wielkości, z których część została zapakowana jeszcze przez Kazimierza Sabbata - tak było np. z niektórymi partiami korespondencji z lat czterdziestych, pięćdziesiątych i sześćdziesiątych, która miała chwilami bardziej lub mniej chronologiczny układ. Faktycznie pierwszą czynnością było wyjmowanie z kilkunastu różnych opakowań tysięcy kart maszynopisów, listów, gazet, wycinków z gazet oraz wstępne wydzielenie materiałów należących do spuścizny i wyodrębnienie dokumentacji niemającej charakteru archiwalnego. Do tej ostatniej zaliczono często występujące teksty powielane, czyste kartki papieru, liczne gazety niezwiązane bezpośrednio z twórcą spuścizny oraz pojedyncze, powielane kartki i wycinki z prasy, których nie można było bliżej zidentyfikować.

Podczas wstępnych prac zdecydowano o metodach porządkowania i układzie całości, aby na etapie segregacji i ustalania granic spuścizny formować odpowiednie grupy materiałów. Po zapoznaniu się z literaturą na temat spuścizn archiwalnych ${ }^{19}$ oraz z Wytycznymi opracowania spuścizn archiwalnych po

19 Por.: Z. Kolankowski, Granice spuścizny archiwalnej, Archeion, t. 57, 1972; A. Piber, Spuścizna - jej istota, zawartość, uktad, metody porządkowania, Archeion, t. 42, 1965; A. Kulecka, Spuścizny $w$ archiwach, bibliotekach $i$ muzeach $w$ Polsce, Archeion, t. 100, 1999. 
uczonych wydanymi przez Polską Akademię Nauk ${ }^{20}$ uznano, że te ostatnie, wobec nieistnienia układu nadanego przez twórcę (jak w przeważającej większości spuścizn), mogą być wykorzystane do uporządkowania materiałów Kazimierza Sabbata. Było to tym bardziej słuszne, że wszystkie działy występujące w schemacie proponowanym w Wytycznych były w omawianej spuściźnie reprezentowane. Następnie w każdej grupie wydzielono mniejsze działy tematyczne, w których dokumenty uporządkowano w większości chronologicznie, czasem rzeczowo-chronologicznie. Wyjątkiem jest korespondencja, która otrzymała układ alfabetyczny według adresatów lub nadawców - oddzielnie dla korespondencji wychodzącej oraz wpływającej. Nieliczne grupy materiałów były przez Sabbata przechowywane w opisanych przez niego skoroszytach, teczkach kartonowych - dotyczyły one z reguły konkretnej sprawy czy wydarzenia i tak też je pozostawiono, ewentualnie uzupełniając odnalezionymi dokumentami. Stąd obecność takich jednostek archiwalnych, jak np.: Rada Jedności Narodowej, Skarb Narodowy, Sprawa Juliusza Sokolnickiego, Światowy Zjazd Polski Walczącej 1966, z których nie wyłączano nawet korespondencji, chociaż ta, z założenia, znajduje się w innym miejscu spuścizny.

Nazwa spuścizny - Archiwum Kazimierza Sabbata - powstała w sposób naturalny dla tego rodzaju materiałów archiwalnych ${ }^{21}$, przede wszystkim jednak z uwagi na fakt, że badacze wcześniej korzystający z tego archiwum (Jacek K. Danel, Andrzej Friszke) pod tą nazwą wprowadzili do obiegu naukowego dokumenty z niego pochodzące ${ }^{22}$. Granice chronologiczne spuścizny obejmują lata życia twórcy: 1922-1989, wyznaczają je: najstarszy zachowany dokument oraz nekrologi, wspomnienia pośmiertne i listy kondolencyjne. Do spuścizny dołączono materiały przekraczające rok 1989 - głównie rocznicowe materiały wspomnieniowe oraz opracowania biograficzne.

Archiwum Kazimierza Sabbata było wykorzystywane do badań naukowych w znikomej - wspomnianej już - uporządkowanej części, zanim uzyskało obecny stan i układ. Stąd cytowane w publikacjach dokumenty pochodzące z tego archiwum niekiedy trudno będzie odnaleźć - wcześniej nie miały one żadnych sygnatur, jedyną wskazówką pozostaje rok wytworzenia i treść. Aktualnie podstawową pomoc archiwalną stanowi inwentarz archiwalny z elementami sumariusza, sporządzony według tradycyjnego wzoru

20 Wytyczne opracowania spuścizn archiwalnych po uczonych, oprac. H. Dymnicka, Z. Kolankowski, Warszawa 1990.

${ }^{21} \mathrm{~W}$ archiwistyce występują różne terminy na określenie zespołów archiwalnych proweniencji prywatnej: spuścizny archiwalne lub rękopiśmienne, kolekcje, papiery, zbiory. Czasem występuje nazwa „archiwum” tej lub innej osoby.

22 J. K. Danel, Kazimierz Sabbat polityk, s. 524 (bibliografia); A. Friszke, dz. cyt., s. 497 (bibliografia). 
obowiązującego w polskiej archiwistyce i w tradycyjnej formie książkowej. Opis większości materiałów sporządzono na poziomie pojedynczego dokumentu, pisma, wyjątkiem są materiały niezwiązane bezpośrednio z twórcą spuścizny oraz niepoddające się takiemu opisowi.

Po opracowaniu Archiwum Kazimierza Sabbata obejmuje około 6 metrów bieżących dokumentacji (bez uwzględnienia materiałów fotograficznych i fonograficznych), razem 136 j.a., zgrupowanych w ośmiu działach (scharakteryzowanych poniżej). Archiwum znajduje się w Londynie i jest własnością i w dyspozycji rodziny Kazimierza Sabbata. Za zgodą rodziny i rekomendacją ośrodka naukowego (uniwersytetu, instytutu naukowego, archiwum) jest również udostępniane dla badaczy.

Charakterystyka archiwalna każdego działu jest odmienna z uwagi na rodzaj zawartego w nim materiału. I tak, w dziale pierwszym zgromadzono głównie oryginalną prasę, kompletne numery gazet i czasopism, w nielicznych przypadkach tylko zachowane ich fragmenty (wycinki), w których opublikowano artykuły Sabbata. Znalazły się tu również jego liczne rękopisy i maszynopisy (oryginały i kopie maszynowe) artykułów i przemówień. Najbardziej zróżnicowana i nie do końca możliwa do zidentyfikowania grupa to notatki rękopiśmienne z lat 1943-1989. Znaczna ich część nie jest datowana, często są to wyrwane z notesów kartki, kawałki bibułek lub serwetki papierowe. Grupa trzecia zawiera dokumenty osobiste związane z życiem Sabbata, najczęściej oryginalne formularze, druki, a także notesy i kalendarze. Najliczniej występują w spuściźnie maszynopisy - zarówno oryginały, jak i kopie - i one właśnie dominują w działach drugim, czwartym, piątym, szóstym i siódmym. Natomiast w dziale ósmym obejmującym załączniki zgromadzono - oprócz maszynopisów - broszury, wycinki z prasy i liczne druki.

Całość spuścizny zachowała się w dość zadowalającym stanie fizycznym, chociaż widać na wielu materiałach upływ czasu i skomplikowane koleje losu. Starsza część, powstała na słabej jakości papierze, dziś ulega pokruszeniu, a np. maszynowe kopie na papierze przebitkowym i fotokopie - wyblakły.

Prawie cała spuścizna powstała w języku polskim, ale czasami występuje język angielski (część korespondencji, dokumentów urzędowych i artykułów), sporadycznie inne.

Do spuścizny należą również materiały fotograficzne oraz fonograficzne. Luźne fotografie związane z działalnością publiczną i wykonywaną przez Kazimierza Sabbata pracą zostały uporządkowane w sposób chronologiczno-rzeczowy. Niewielka grupa fotografii znajduje się w albumach. Część dotycząca życia prywatnego pozostaje nieopracowana. Materiały fonograficzne (taśmy magnetyczne) nie zostały opracowane z uwagi na niemożliwość ich identyfikacji (brak sprzętu). 
Archiwum Kazimierza Sabbata składa się z ośmiu działów.

Dział I został nazwany „Prace Kazimierza Sabbata” i podzielony na cztery części: 1 - teksty opublikowane, 2 - maszynopisy i rękopisy tekstów publicystycznych, przemówień, wystąpień i mów okolicznościowych, 3 - wywiady prasowe, audycje radiowe, 4 - notatki różne (rękopiśmienne). Zgromadzono w tym miejscu broszury autorstwa Sabbata zawierające głównie jego exposé jako prezesa Rady Ministrów RP i sprawozdania z pracy rządu przez niego kierowanego. Dużo miejsca zajmują gazety emigracyjne, wychodzące zwłaszcza w Anglii („Rzeczpospolita Polska”, „Tydzień Polski”, „Polish Affairs”, „Dziennik Polski i Dziennik Żołnierza”), ale i w innych krajach („Kombatant w Ameryce”, „Tygodnik Polski. Pismo Wolnych Polaków w Australii i Nowej Zelandii”, „Głos Polski. La Voz de Polonia. Organ Związku Polaków w Argentynie”, „Czas. Polish Time” - niezależne bezpartyjne polskie pismo poświęcone wychodźstwu polskiemu w Ameryce Północnej), w których przez wiele lat, bardziej lub mniej regularnie, ukazywały się artykuły publicystyczne twórcy, komentujące przede wszystkim historyczne i bieżące wydarzenia polityczne związane z Polonią na świecie lub wydarzeniami w kraju czy na świecie. Wystarczy wymienić, wśród około stu publikacji autorstwa Kazimierza Sabbata, które ukazały się między 1961 a 1989 rokiem, np. Czterdziestolecie Jatty ${ }^{23}$, Polska po wielkich strajkach ${ }^{24}$, Rok spoteczeństwa niezależnego $^{25}$, Upadek Nixona ${ }^{26}$, Europa zjednoczona ${ }^{27}$, Obrona praw cztowieka ${ }^{28}$. Warto zwrócić uwagę na artykuły związane $\mathrm{z}$ wprowadzeniem stanu wojennego w Polsce, które miały m.in. za zadanie zwrócić uwagę wolnego świata na sytuację Polaków: Dziatalność emigracji niepodlegtościowej ${ }^{29}$, 1982, rok wojny Jaruzelskiego ${ }^{30}$. Treść publicystyki Sabbata stanowi zapis najnowszych dziejów Polski widzianych z perspektywy emigracji, czy raczej - wolnego świata.

Do wielu gazet dołączono odnalezione maszynopisy lub rękopisy publikowanych tekstów, które wraz z naniesionymi poprawkami pozwalają śledzić tok myśli i kolejne etapy powstawania artykułów. Pozostałe maszynopisy i rękopisy różnych tekstów znalazły się w grupie drugiej, oprócz notatek, projektów pism, mów i wystąpień z okazji różnych uroczystości. Wśród chro-

23 Rzeczpospolita Polska, z dn. 1 lutego 1986 r.

24 Rzeczpospolita Polska, z dn. 10 października 1980 r.

25 Czas. The Polish Time, z dn. 23 stycznia 1988 r.

26 Tydzień Polski, z dn. 24 sierpnia 1974 r.

27 Tydzień Polski, z dn. 31 maja 1975 r.

28 Rzeczpospolita Polska, ze stycznia 1977 r.

29 Tygodnik Polski. Pismo Wolnych Polaków w Australii i Nowej Zelandii, z dn. 8 maja $1983 \mathrm{r}$.

30 Rzeczpospolita Polska, ze stycznia 1983 r. 
nologicznie ułożonych materiałów znalazły się m.in.: apel o pomoc dla ofiar wypadków czerwcowych 1956 roku w Polsce, notatka dotycząca oceny wydarzeń w 1967 roku na Bliskim Wschodzie, mowa z okazji objęcia urzędu prezydenta RP, mowa z okazji 90 urodzin prezydenta Edwarda Raczyńskiego $^{31}$, notatka w sprawie przeniesienia prochów gen. W. Sikorskiego do Polski. Kilkanaście pozycji liczy grupa zawierająca teksty wywiadów Sabbata udzielonych różnym czasopismom i gazetom oraz rozgłośni Radia Wolna Europa. Notatki rękopiśmienne z lat 1943-1989 to bardzo zróżnicowana i nie do końca możliwa do zidentyfikowania grupa dokumentów. Znaczna ich część jest niedatowana, zapiski trudno powiązać z jakimkolwiek wydarzeniem, często są to kawałki bibułek lub serwetki papierowe, wobec czego nadanie im układu było niemożliwe.

W dziale II - „Materiały działalności twórcy spuścizny” - znalazły się dokumenty dotyczące działalności społeczno-politycznej Kazimierza Sabbata. Wydzielono tu dwanaście grup materiałów. Pierwsza zawiera Dzienniki Ustaw RP z lat 1936-1989 - egzemplarze zgromadzone dość przypadkowo, głównie dotyczące urzędu i zakresu działania prezydenta i premiera rządu RP na uchodźstwie oraz spraw wydatków i przychodów rządu. Są tu również dekrety i zarządzenia prezydenta RP oraz projekty z lat 1975-1987, zwłaszcza o wydatkach i dochodach państwowych. Grupa druga obejmuje orędzia, przemówienia i odezwy prezydenta - począwszy od wygłaszanych przez Stanisława Ostrowskiego ${ }^{32}$ w latach 1976-1978 i Edwarda Raczyńskiego w latach 1979-1986 - głównie okolicznościowe z okazji różnych rocznic i Nowego Roku. Jako oddzielną grupę wydzielono materiały związane ze sprawą następstwa na urzędzie prezydenta RP na uchodźstwie, z wyznaczeniem K. Sabbata na następcę prezydenta E. Raczyńskiego, z głośną dyskusją $\mathrm{w}$ środowiskach emigracyjnych na świecie na temat tzw. legalizmu polskiego na emigracji oraz pierwszych dni prezydentury Sabbata. Są to głównie materiały prasowe związane z atakami na Sabbata, w tym artykuły Zbigniewa Racięskiego, Stefana Korbońskiego, Juliusza Szygowskiego czy Jerzego Lerskiego. Do kolejnej grupy zaliczono memoranda i oświadczenia rządu RP, począwszy od protestu przeciwko uchwałom konferencji w Jałcie ze stycznia 1945 roku, poprzez sprawę Herberta Czai ${ }^{33}$, konferencję w Belgradzie

31 Edward Raczyński (1891-1993), dyplomata, polityk i pisarz, prezydent RP na uchodźstwie w 1. 1979-1986.

32 Stanisław Ostrowski (1892-1982), lekarz, ostatni polski prezydent Lwowa i trzeci prezydent RP na uchodźstwie w 1. 1972-1979.

33 Herbert Czaja (1914-1997) był przewodniczącym niemieckiego Związku Wypędzonych. W Polsce uczyniono z niego symbol „niemieckiego odwetu”, znany był jako 
w 1971 roku, stan wojenny w Polsce, konferencję bezpieczeństwa i współpracy w Helsinkach w 1975 roku, obronę praw człowieka, amnestię w Polsce. Grupa zatytułowana: „Praca ministerstw” obejmuje materiały wytworzone przez kilka resortów rządu emigracyjnego, w tym najliczniej reprezentowane Ministerstwo Spraw Zagranicznych, następnie ministerstwa: Spraw Wojskowych, Spraw Krajowych, Spraw Społecznych, ds. Emigracji, Informacji, Skarbu. Warto zwrócić uwagę na znane analizy sytuacji międzynarodowej autorstwa Jana Starzewskiego ${ }^{34}$, analizy zawartości prasy zagranicznej pod kątem spraw polskich, materiały dotyczące kontaktów polsko-czeskich, polsko-ukraińskich, polsko-węgierskich w warunkach emigracji. W oddzielnej grupie umieszczono notatki, oświadczenia i korespondencję związane z pracą prezydenta, premiera i rządu RP na uchodźstwie. Tematyka tychże jest bardzo zróżnicowana, dotyczy głównie lat 1976-1988 i zawiera m.in. sprawy działalności niepodległościowej na terenie USA i Kanady, zaprzysiężenia Edwarda Raczyńskiego i sformowania nowego rządu w roku 1979 czy kalendarze czynności prezydenta. Kolejne w tym dziale grupy materiałów dotyczą podróży zagranicznych Sabbata (do USA i Kanady, RFN-u, Australii i Nowej Zelandii, Argentyny, Belgii). W materiałach tych znalazły odzwierciedlenie przede wszystkim problemy związane z organizowaniem funduszy na Skarb Narodowy. Zgromadzone w tym dziale dokumenty ukazują sposób funkcjonowania prezydenta RP na emigracji, np. finansowanie jego podróży przez organizacje emigracyjne i prywatnych sponsorów, programy wizyt i ważne sprawy poruszane podczas oficjalnych spotkań oraz na bankietach i w kuluarach. Zachowały się nie tylko drukowane programy pobytu, ale też bilety, dokumenty ubezpieczeniowe, rachunki za hotele i z wymiany pieniędzy, zaproszenia na spotkania z prezydentem i różna korespondencja poświęcona organizacji wyjazdów.

W kolejnych grupach znalazły się nieliczne materiały dotyczące budynku przy 43 Eaton Place w Londynie, gdzie znajdowała się siedziba rządu RP na uchodźstwie, oraz materiały odnoszące się do odznaczeń: Orderu Odrodzenia Polski, Krzyża Oficerskiego Polonia Restituta, a także projekty uchwał o ustanowieniu Krzyża i Medalu Tysiąclecia Państwa Polskiego i Polski Chrześcijań-

przeciwnik granicy na Odrze i Nysie. W 1974 r. został przyjęty w gmachu rządu emigracyjnego RP i rozmawiał m.in. z prezydentem Ostrowskim, ówczesnym premierem Alfredem Urbańskim i wieloma innymi politykami. Fakt ten nie został oficjalnie ogłoszony, a cała sprawa wywołała wielomiesięczne konflikty, kłótnie, które spowodowały zmniejszenie zaufania do rządu emigracyjnego.

${ }^{34}$ Jan Starzewski (1895-1973), dyplomata i publicysta; działacz emigracyjny; minister spraw zagranicznych rządu Rzeczypospolitej Polskiej na uchodźstwie. 
skiej (Krzyża i Medalu Millenium), Medalu 50-lecia Odzyskania Niepodległości oraz liczna korespondencja w tych sprawach. Warto podkreślić, że są tu oryginalne wnioski odznaczeniowe ( $\mathrm{w}$ tym z lat 1965-1972 w pierwotnym układzie), akty nadania i ewidencja odznaczonych Krzyżem Zasługi.

Ważne z punktu widzenia spraw polskich na emigracji są materiały zgrupowane w kolejnych teczkach: Rady Jedności Narodowej35 i Rady Narodowej z lat 1954-1988. Zasadnicza część materiałów wytworzonych przez obie rady znajduje się w zbiorach archiwum Instytutu Polskiego i Muzeum im. gen. Sikorskiego w Londynie, jednak - jak można przypuszczać - wchodzą one również w skład prywatnych kolekcji poszczególnych członków, czego przykładem jest właśnie Archiwum Kazimierza Sabbata. Tutaj spotykamy głównie materiały związane z organizacją posiedzeń rad i poszczególnych ich komisji, ale także sprawozdania z działalności, notatki ze spotkań, teksty przemówień i referatów, projekty rezolucji i rezolucje. Interesujące są np. notatki Sabbata dotyczące reform Rady Narodowej z 1977 roku.

Kolejna grupa materiałów dotyczy Skarbu Narodowego, w tym Głównej Komisji i komisji terenowych. Zachował się tu m.in. projekt dekretu prezydenta o utworzeniu SN, bogata korespondencja napływająca na adres Sabbata w związku z funkcjonowaniem ogromnego aparatu organizacyjnego SN, liczne sprawozdania z działalności różnych ogniw na całym świecie.

Wśród ponad 200 zachowanych dokumentów Egzekutywy Zjednoczenia Narodowego na uwagę zasługuje bogata korespondencja związana z funkcjonowaniem okręgowych kół i komisji delegatów oraz komunikaty Działu Informacji i Działu Spraw Zagranicznych EZN. Zachowała się również uchwała EZN w sprawie powołania Komisji do spraw Scalenia Obozu Niepodległościowego z 23 listopada 1970 roku oraz protokoły z późniejszych działań tej komisji, sprawozdania z rozmów zjednoczeniowych, korespondencja i inne materiały potwierdzające aktywne starania Kazimierza Sabbata na rzecz zjednoczenia emigracji.

Duże luki chronologiczne występują w zachowanej dokumentacji Niezależnej Grupy Społecznej ${ }^{36}$. W spuściźnie znajdują się głównie materiały od-

35 Rada Jedności Narodowej została powołana w 1954 r. (do 1962 r. pod nazwą: Tymczasowa RJN) w sytuacji odmowy złożenia urzędu przez prezydenta A. Zaleskiego po upływie kadencji. W skład RJN wchodziły stronnictwa polityczne uczestniczące poprzednio w Radzie Politycznej, które odmówiły dalszej współpracy z prezydentem, oraz Stronnictwo Pracy i Liga Niepodległości Polski. Rozwiązała się po zjednoczeniu emigracji w 1972 r.

36 Można przypuszczać, że dokumentacja NGS jest rozproszona w prywatnych kolekcjach, więc nawet te nieliczne materiały, które są znane, mają określoną wartość naukową i informacyjną. 
noszące się do udziału Sabbata w kolejnych posiedzeniach, ale jest m.in. kilka pism z lat 1972-1973 dotyczących rozmów na temat połączenia NGS z konkurencyjnym Niezależnym Ruchem Społecznym i wspólnej reprezentacji w Radzie Narodowej, protokoły walnych zebrań i biuletyny informacyjne.

$\mathrm{Na}$ zainteresowanie zasługują zachowane w spuściźnie materiały harcerstwa polskiego na emigracji, zwłaszcza z lat czterdziestych i pięćdziesiątych, kiedy Sabbat był szczególnie zaangażowany w jego działania. Warto zwrócić uwagę na zeszyty z odręcznymi notatkami Sabbata z zebrań Rady Starszego Harcerstwa z lat 1946-1948. Dokumenty z lat późniejszych mają głównie charakter okolicznościowy, ale zdarzają się i takie, jak np. uwagi do referatu o sytuacji harcerstwa w PRL-u w stanie wojennym czy notatki na temat opracowywanej historii harcerstwa na emigracji.

Grupa materiałów zatytułowana „Kościół polski na uchodźstwie” obejmuje 30 dokumentów w większości bezpośrednio niezwiązanych z twórcą spuścizny. Wśród nich warto wymienić historię pierwszego polskiego kościoła w Nowej Zelandii, mowę Sabbata na otwarcie zebrania z okazji 25-lecia ogłoszenia Autokefalii Polskiego Kościoła Prawosławnego, porządek uroczystości z okazji wizyty papieża Jana Pawła II w Wielkiej Brytanii.

Pokaźną grupę materiałów stanowią dokumenty ponad osiemdziesięciu organizacji, instytucji politycznych i społecznych polskiej emigracji, w których działalność w różny sposób był zaangażowany Kazimierz Sabbat. Warto wymienić wśród nich np. European Liaison Group, Free Poland Combat Organization (Organizacja Bojowa Wolna Polska), Fundusz Pomocy Krajowi, Fundusz Obrony Wolności Słowa i Praw Ludzkich w Polsce. Najliczniej reprezentowane jest Stowarzyszenie Polskich Kombatantów. Kilka teczek materiałów odnosi się do organizowanych przez polską emigrację: Światowego Zjazdu Polski Walczącej w 1966 roku, Ogólnego Zjazdu Polaków w Londynie w 1978 roku, Światowego Zjazdu Jedności z Walczącym Krajem w 1979 roku, Kongresu Kultury Polskiej na Obczyźnie i innych imprez. Wśród zachowanych dokumentów znajdują się listy uczestników, teksty wygłaszanych referatów, programy spotkań i liczna korespondencja.

Dział III obejmuje materiały biograficzne podzielone na sześć grup. W grupie dokumentów osobistych znalazły się m.in.: dowód osobisty wydany w 1934 roku, legitymacje studenckie: Szkoły Nauk Politycznych w Warszawie i Uniwersytetu Warszawskiego; książeczka wojskowa z 1939 roku, zaświadczenie uchodźcy na Węgrzech z 1939 roku czy Military Identity Card, przepustki z lat 1940-1941; książeczki z kuponami ubraniowymi, karty członkowskie Ogniska Polskiego, legitymacja delegata na Ogólny Zjazd Polaków w Wielkiej Brytanii w 1962 roku. Kolejna grupa obejmuje metryki, świadectwa, umowy o pracę, odwołania i mianowania, dyplomy, sprawy zdrowia 
i inne, w tym m.in.: świadectwa urodzenia i chrztu, zaproszenie na ślub Sabbata z Anną Sulik, życiorysy, dzienniki klasowe gimnazjum w Mielcu z lat 1927-1932; zaświadczenie z Uniwersytetu J. Piłsudskiego o zdaniu egzaminu z czwartego kursu studiów i otrzymaniu dyplomu magistra praw, umowa o pracę w Urzędzie Oświaty i Spraw Szkolnych; dokumenty związane ze służbą wojskową, jak np. mianowanie plut. podchorążego Kazimierza Sabbata na stopień aspiranta-podchorążego w korpusie piechoty; dokumenty piastowania różnych funkcji państwowych, np.: powołanie i odwołanie ze stanowiska członka Egzekutywy Zjednoczenia Narodowego, zaświadczenie o członkostwie w Radzie Jedności Narodowej, mianowania na stanowiska: prezesa Rady Ministrów, ministra sprawiedliwości, ministra spraw krajowych, ministra spraw zagranicznych, zwolnienie ze stanowiska ministra spraw zagranicznych i powierzenie sprawowania obowiązków do czasu sformowania nowego rządu; mianowanie harcmistrzem ZHP w 1939 roku, zaświadczenie o pełnieniu obowiązków komendanta Ośrodka Harcerskiego w obozie dla internowanych na Węgrzech. Zachowały się też różne dyplomy nadania odznaczeń i odznak pamiątkowych, a nawet świadectwa szczepień i wyniki badań lekarskich. Ważna grupa materiałów w tej spuściźnie to dzienniki i kalendarze. Dzienników zachowało się kilka z lat 1967, 1969, 1985-1989, w niektórych zapisano nieliczne strony, natomiast kalendarzyki z zapiskami o spotkaniach i różnych sprawach do załatwienia pochodzą z lat 1940-1988.

Ważny element prezentowanej spuścizny to prasa, stąd wydzielona grupa nazwana „Prasa o działalności politycznej i społecznej K. Sabbata”, obejmująca gazety i wycinki z gazet zawierające artykuły związane z piastowanymi przez niego stanowiskami i funkcjami oraz wizytami zagranicznymi w latach 1958-1989. Oddzielną grupę stanowią kondolencje po śmierci Sabbata - kilka tomów kart okolicznościowych skierowanych do rodziny, oraz wyodrębniony dział: „Prasa po śmierci K. Sabbata”, czyli gazety, w których zamieszczano artykuły biograficzne i omawiające jego dokonania oraz artykuły ukazujące się w kolejne rocznice jego śmierci.

Dział IV to korespondencja z lat 1943-1989. Korespondencja zwykle stanowi o wartości spuścizny, zawiera informacje, które nie znajdują odzwierciedlenia w oficjalnej dokumentacji, i nie inaczej jest w przypadku listów do i od Kazimierza Sabbata. W pierwszej kolejności jest to korespondencja wysyłana przez Sabbata w postaci maszynowych kopii listów, na papierze przebitkowym, często dzisiaj wyblakłym. W większości jest to korespondencja mało osobista, raczej kurtuazyjne podziękowania za listy. Wydaje się, że listy o charakterze prywatnym lub dotyczące spraw ważnych Sabbat pisał odręcznie i w jednym egzemplarzu. Inaczej było z korespondencją przychodzącą, której zachowała się tylko część (około 2000 listów), co jest widoczne w lu- 
kach chronologii. Wśród nadawców, z którymi Sabbat utrzymywał kontakt listowny, znajduje się wiele znanych nazwisk (Adam Ciołkosz, Jerzy Giedroyć, Janusz Zawodny, Jan Nowak, Leszek Moczulski) i wiele mniej znanych szerokiemu gronu, ale aktywnych w życiu polskiej emigracji (m.in. Janusz Bućko, Władysław Dembski, Olgierd Dunin-Borkowski, Ludwik Frendl, Aleksander Kajkowski, Leonidas Kliszewicz, Marek Mażyński, Stanisław i Ewa Gieratowie, Tadeusz Podgórski, Władysław Sosulski, Jerzy J. Zalewski, Zygmunt Szadkowski czy wieloletni przyjaciel Kazimierz Łukomski), w tym kilku cudzoziemców sprzyjających polskiej sprawie niepodległościowej (sir Bernard Braine, Bruce Brown z Anglo-Polish Society). Wiele listów zachowało się wraz z kopertami oraz różnymi załącznikami w postaci np. wycinków z prasy, opracowań na różne tematy, fotografii, kopii dokumentów. Charakterystyczną cechą nadsyłanych do Sabbata listów jest w większości ich półprywatny charakter - oprócz informacji oficjalnych, żywo zajmujących uczestników życia politycznego emigracji, pojawiają się sprawy czysto osobiste, dotyczące najczęściej życia rodzinnego.

Do działu V włączono materiały o twórcy zespołu, w tym prace biograficzne o twórcy spuścizny autorstwa Jacka Danela i Małgorzaty Trębickiej, a także wiersze jemu poświęcone.

W dziale VI znalazły się nieliczne materiały rodzinne, w tym m.in. związane z życiem i walką gen. Nikodema Sulika, który był ojcem Anny Sabbatowej.

Dział VII obejmuje materiały osób obcych. Umieszczono w nim m.in. korespondencję różnych osób, co prawda nieadresowaną do twórcy, ale która z konkretnych powodów znalazła się u niego - głównie w postaci kopii. Znalazły się tu również materiały związane ze sprawą Juliusza Sokolnickiego ${ }^{37}$, który mianował się drugim prezydentem na uchodźstwie.

Ostatni - VIII dział - to załączniki w postaci: ulotek, druków ulotnych, czasopism, wycinków i przedruków z prasy; książek, broszur, czasopism dotyczących harcerstwa i skautingu; druków, prasy bezdebitowej i ulotek organizacji podziemnych ukazujących się w kraju przed 1989 rokiem; opracowań różnych autorów oraz biuletynów Radia Free Europe. Na szczególną uwagę zasługują materiały będące skutkiem zainteresowania, współpracy i wspiera-

37 Juliusz Nowina-Sokolnicki (ur. 1920) - polski polityk emigracyjny, przedstawiający się jako legalny Prezydent Wolnej Polski na Wychodźstwie w latach 1972-1990, przez znaczną część polskiej emigracji traktowany jako oszust. Jego działalność „prezydencka” żywo zajmowała środowiska emigracyjne. Por. Juliusz Nowina-Sokolnicki [on-line]. [Dostęp 1 września 2008 r.]. Dostępny w World Wide Web: http://pl.wikipedia. org/wiki/Juliusz_Nowina-Sokolnicki. 
nia przez Sabbata działalności niepodległościowej w Polsce, w tym unikatowe druki ulotne czy egzemplarze gazetek z lat siedemdziesiątych i osiemdziesiątych.

O potrzebie i wadze wykorzystywania do badań naukowych materiałów wchodzących w skład spuścizn archiwalnych nie ma potrzeby nikogo przekonywać. Archiwalia te dotyczą wszystkich dziedzin życia politycznego, społecznego oraz kulturalnego i nie inaczej jest w przypadku spuścizn polskich emigrantów. Przede wszystkim w spuściznach odzwierciedla się dorobek ich twórców, ich działalność i kontakty. Informacje w nich zgromadzone stanowią istotne uzupełnienie materiałów proweniencji oficjalnej, o charakterze urzędowym. To z nich można dowiedzieć się o osobistych motywach podejmowanych decyzji, ich okolicznościach i wzajemnych relacjach między ludźmi. Stąd ważne znaczenie dla rekonstrukcji wydarzeń nie tylko pamiętników i osobistych zapisków, ale głównie korespondencji. W przypadku spuścizn emigracyjnych uzyskujemy szersze spojrzenie na relacje oraz związki intelektualne i towarzyskie między polonijnymi środowiskami twórczymi i politycznymi a krajem oraz środowiskami emigracyjnymi innych państw. Spuścizna Kazimierza Sabbata należy do najwartościowszych ze względu na jego miejsce w strukturach emigracji. Zawartość spuścizny, mimo istniejących braków, świadczy nie tylko o skrupulatności twórcy w dokumentowaniu swojego życia, ale przede wszystkim o samym życiu, bogatym i aktywnym na wielu polach - od spraw prywatnych, przez działalność gospodarczo-handlową, do społecznej i politycznej, zawsze blisko Polski, mimo że na emigracji.

\section{Archives of Kazimierz Sabbat}

Summary

There has been a discussion led for a few years concerning the documentation generated and collected by Polish emigration all around the world. Its main subject has mainly concerned the place of documents storage but it also has touched the problem of proper preservation, analysis and accessibility. Archival heritage constitutes the biggest part of these materials. On one hand one can observe tendency to bring private heritage to the country; on the other hand, in emigrant community there is pressure to leave heritage in places connected with its authors. The vast of private heritage is stored by Polonia institutions all over the world and by foreign archives whereas the substantial part is still in private hands. The condition of collections varies a lot. It is beyond any 
discussion that present owners of often valuable materials need professional, fair help if the documents are still to serve national wealth.

Kazimierz Sabbat (1913-1989) was the last but one president of the Polish Republic in Exile, earlier longstanding prime minister and minister of foreign affairs of emigration government, political and social activist of Polonia in Great Britain. His archives, which are in private hands, include archival materials of a few decades of his life. These materials had been collected by Sabbat since his student time, during the war, emigration and to his death. All these materials reflect in an excellent way not only different fragments of political and private life but the author's character features as well.

In 2001-2008 this heritage was analysed and the inventory according to Wytyczne opracowania spuścizn archiwalnych po uczonych (Guidelines for arrangement and description on scientists private papers), edited by PAN (Polish Academy of Sciences) was produced. Chronological borders of the heritage are from 1922 to 1989. The archives of Kazimierz Sabbat include about 6 meters (linear) of documentation (not taking into account photographic and phonographic materials); together these are 136 archival units, grouped into 8 sections.

Materials collected in the archives of Kazimierz Sabbat include, among others, his published texts, typescripts and manuscripts of articles and speeches; documentation concerning political and social activity of Kazimierz Sabbat; biographic materials, correspondence from 1943 to 1989; materials about the author of archives (including biographies), materials of other people and attachments such as: leaflets, ephemeral prints, magazines, excerpts and reprints from press; books, brochures, magazines concerning scouting; prints, press beyond the scope of censorship and leaflets of underground movement appearing in the Poland before 1989.

The heritage of Kazimierz Sabbat is the most valuable due to Sabbat's position in Polish emigration structure after World War II. 